\title{
Analysis of the fire resistance of normal wooden doors exposed to fire conditions
}

\author{
Carina Panno (Main author) \\ University of Vale do Rio dos Sinos/UNISINOS, Civil Engineering Department \\ 93022-750, São Leopoldo (Brazil) \\ carinapanno@yahoo.com.br \\ Jordana Gonçalves \\ University of Vale do Rio dos Sinos/UNISINOS, Civil Engineering Department \\ 93022-750, São Leopoldo (Brazil) \\ jordanagoncalves@live.com
}

\section{Gustavo Prager}

University of Vale do Rio dos Sinos/UNISINOS, Civil Engineering Department 93022-750, São Leopoldo (Brazil)

gprager@unisinos.br

\section{Fabricio Longhi Bolina}

University of Vale do Rio dos Sinos/UNISINOS, Civil Engineering Department 93022-750, São Leopoldo (Brazil)

fabriciolb@unisinos.br

\section{Bernardo Fonseca Tutikian (Corresponding author)}

University of Vale do Rio dos Sinos/UNISINOS, Civil Engineering Department 93022-750, São Leopoldo (Brazil)

Universidad de la Costa, CUC, Department of Civil and Environmental

Calle 58 \# 55-66, Barranquilla, Atlántico (Colombia)

bftutikian@unisinos.br

\author{
Manuscript Code: 14108 \\ Date of Acceptance/Reception: 01.08.2020/24.11.2019 \\ DOI: 10.7764/RDLC.19.2.359
}

\begin{abstract}
Meeting passive and active protection requirements in buildings has brought about demands for new systems, materials, equipment, and even design requirements like the access to housing units with doors that have a minimum fire-resistance rating of 30 minutes. For existing buildings, though, it is not always possible to adapt them to current government regulations, and normal low-cost doors usually do not comply with compartmentalization requirements. Therefore, this study aimed to evaluate the fire resistance of normal wooden doors and low-cost compensatory measures to increase the protection of existing building elements. The lab tests were performed on real-scale wooden door prototypes. Moreover, three protective solutions were tested while added to the doors: (a) fire-rated gypsum boards, (b) cement boards, (c) steel sheet with polyethylene terephthalate felt, in addition to the reference door. It was noted that only the prototype with cement boards managed to resist for 30 minutes. This result evidences the existence of alternative low-cost solutions that can be used in simpler buildings, although some of the usual options may not be able to meet the requirement.
\end{abstract}

Keywords: Fire safety, Fire door, Existing buildings, Fire resistance, Design requirements.

Regulating buildings is not an easy task due to the impossibility to demand standard safety measures, since the minimum necessary adaptations might not be executable because of construction characteristics (Brentano, 2015). According to Ono (2002), old buildings usually have open stairs in their original configuration to connect each level. This characteristic may reduce user safety, mainly when they are totally open, that is, when there are no doors or walls that separate them from the other rooms (Ono, 2002).

The materials used to structure a building may affect fire development characteristics, that is why it is essential to study the thermal performance of building elements at high temperatures, considering that they affect overall building safety (Asimakopoulou et al., 2015). As per Carlo et al. (2008), the use of new materials that lack control over fire resistance 
and reaction to fire brings about several hazards. For construction materials to meet fire resistance requirements, it is often necessary to have them protected with thermal insulation products (Silva, 2010).

Reaction to fire is described by Pinto \& Calil (2002) as physical and chemical transformations that take place when the materials have been exposed to controlled fire conditions. Reaction-to-fire testing intends to measure the contribution of the materials to fire spread and growth (Faccio \& Silva, 2016). The assessments are performed through tests for: (a) surface flame spread, (b) combustibility, (c) calorific value, (d) specific optical density of smoke, (e) smoke toxicity (Pinto \& Calil, 2002).

According to Troitzsch (1983), the reduction of risk of fire from combustible materials such as wood, plastic and textiles is accomplished in houses and workplaces with the use of proper flame-retardant treatments. These treatments can stop or delay the beginning of a fire, providing enough time for evacuation and reducing the risk of fire spread (Purser, 2000). Gwynne \& Boyce (2016) complement that this risk increases when the users are asleep, making compartmentalization even more important to keep smoke from spreading.

In the last century, the design of buildings underwent significant improvements owing to innovative architectural solutions driven by the use of new materials and construction technologies for doors (Brentano, 2015). Silva (2010) adds on the diversity of materials for fire doors, which can be made of wood or steel, simultaneously, with addition of other materials such as gypsum and mineral wool.

In order to maintain performance and fire safety requirements, it is necessary to balance the use of multiple materials, so that their design does not end up hindering user evacuation (Izydorczyk et al., 2017; Gil et al., 2017). Regarding wooden doors, the authors complement that wood carbonization occurs on the heated side and makes the top and bottom edges of the door leaf deform towards the fire. Pacheco et al. (2018) explain that the rate at which wood gets carbonized is directly related with the density of the material. Babrauskas (2005) concludes that the rate is higher at joints or sharp edges, so carbonization is faster there than at other parts of the door.

In the context of adequacy of buildings, mainly multi-level finished ones that have no technically viable means to meet the regulatory requirements of compartmentalization, the impact is more severe, because the hallways that lead to each housing unit have been considered as escape routes that give access to enclosed stairs. Thus, the access points of housing units must have a minimum fire-resistance rating of 30 minutes (ABNT NBR 15281:2005).

Therefore, this study aimed to evaluate, experimentally, compensatory low-cost measures to aggregate the fireresistance rating of semi-solid normal wooden doors, which are commonly found in social interest buildings, bearing in mind that this is considered as the most critical situation for meeting fire resistance requirements. Hence, four similar unpainted doors with $210 \times 90 \mathrm{~cm}$ and thickness of $3.5 \mathrm{~cm}$ were analyzed, namely, the reference door and 3 protection solutions that could be applied to existing elements: (a) fire-rated gypsum boards, (b) cement boards with and intumescent paint and strips, (c) polyethylene terephthalate felt with metal sheet, paint and intumescent strips. Since polyethylene terephthalate is a combustible material, the felt had its ignitability assessed as per EN ISO 11925-2 (EN ISO, 2010). The fire resistance test for door and shutter assemblies followed the criteria set by NBR 6479 (ABNT, 1992), which regards thermal insulation, integrity and mechanical strength. Deformations, internal and external temperatures, and release of smoke and flames were monitored as well. The study was then divided into four sections: (1) introduction, (2) materials and methods; (3) results and discussion; and (4) conclusion.

Methodology

\section{Materials Used}

\section{Wooden Doors}

There were four semi-solid wooden doors, named D1, D2, D3 and D4. The comparison of results was made possible owing to the addition of different materials to an identical substrate. The doors were made of Pinus wood, with smooth finishing and leaf dimensions of $210 \times 90 \mathrm{~cm}$ and $3.5 \mathrm{~cm}$ of thickness.

For the fire resistance test of doors D3 and D4, intumescent paint and intumescent strips were used. The paint coat was designed for use in interiors and exteriors, on wooden substrates, concrete, masonry and metal sheets. The strips were installed within the door frame, contouring the side and top edges of the leaf, so as to keep smoke from passing through the openings of the door in fire condition, seeking to improve system integrity. 


\section{Fire-Rated Gypsum Boards and Cement Boards}

The fire-rated gypsum board was pink-colored, with dimension of $240 \times 120 \mathrm{~cm}$ and thickness of $1.25 \mathrm{~cm}$. The values for thermal conductivity, specific heat capacity and bulk density were $0.21 \mathrm{~W} / \mathrm{m} . \mathrm{K}, 1000 \mathrm{~J} / \mathrm{kg} . \mathrm{K}$ and $800 \mathrm{~kg} / \mathrm{m}^{3} \mathrm{respectively}$. Additionally, two cement boards with dimensions of $120 \times 240 \mathrm{~cm}$ and thickness of $12 \mathrm{~mm}$ were used.

\section{Metal Sheet with Polyethylene terephthalate (PET) Felt}

Polyethylene terephthalate felt boards were chosen because of their acoustic performance and for being a sustainable material, made from recycled bottles. Thus, the two white-colored felt boards used had dimension of $210 \times 90 \mathrm{~cm}, 5 \mathrm{~cm}$ of thickness and density of $30 \mathrm{~kg} / \mathrm{m}^{3}$.

The metal sheet used to make the final structure for the test with polyethylene terephthalate felt had thickness of 1.3 $\mathrm{mm}$. The dimensions were adjusted to $210 \times 90 \mathrm{~cm}$ for the sake of the door leaf. According to NBR 15220-2 (ABNT, 2005), the values for thermal conductivity, specific heat capacity and bulk density, for metals such as steel and cast iron, were $55 \mathrm{~W} / \mathrm{m} . \mathrm{K}, 0.46 \mathrm{~kJ} / \mathrm{kg} . \mathrm{K}$ and $7800 \mathrm{~kg} / \mathrm{m}^{3}$ respectively.

\section{Masonry Wall}

For the fire resistance tests in vertical furnace, masonry walls were built to install the doors, so as to simulate the most commonly used system for closing and compartmentalizing areas of a building.

\section{Sample Execution}

A. $\quad$ Construction of Masonry Walls: Wall segments were built over the test frames with dimensions of $3.00 \times 3.15$ $\mathrm{m}$ and thickness of $0.20 \mathrm{~m}$.

B. Installation of Wooden Doors in Masonry: The installation of the doors was done according to the instructions and limits for clearance stipulated according to NBR 15930-2 (ABNT, 2018), with the door frame facing the unexposed surface of the test wall as described by NBR 6479 (ABNT, 1992).

The wooden doors were installed on the masonry walls and then the samples were assembled. Table 1 names the samples and Figure 1 depicts the door schematics.

Table 1. Specimen identification. Source: elaborated by the authors.

\begin{tabular}{|c|c|}
\hline Identification & Composition/assembly \\
\hline D1 & - Wooden door \\
\hline D2 & $\begin{array}{l}\text { - Wooden door } \\
\text { - Fire-rated gypsum boards added to the fire-exposed face. }\end{array}$ \\
\hline D3 & $\begin{array}{l}\text { - Wooden door with intumescent paint; } \\
\text { - Polyethylene terephthalate felt board added to the fire-exposed face; } \\
\text { - Metal sheet with intumescent painting on the fire-exposed side; } \\
\text { - Intumescent strip placed within the door frame, next to the side of the door leaf that is directly } \\
\text { exposed to fire. }\end{array}$ \\
\hline D4 & $\begin{array}{l}\text { - Wooden door with intumescent paint; } \\
\text { - Cement board of } 12 \mathrm{~mm} \text { with intumescent paint, placed on the side of the door leaf that is directly } \\
\text { exposed to fire; } \\
\text { - Cement board of } 12 \mathrm{~mm} \text { with intumescent paint, placed on the side that was not exposed to fire; } \\
\text { - Intumescent strip placed within the door frame, next to the side of the door leaf that is directly } \\
\text { exposed to fire. }\end{array}$ \\
\hline
\end{tabular}


Figure 1. Sample identification. Source: elaborated by the authors.

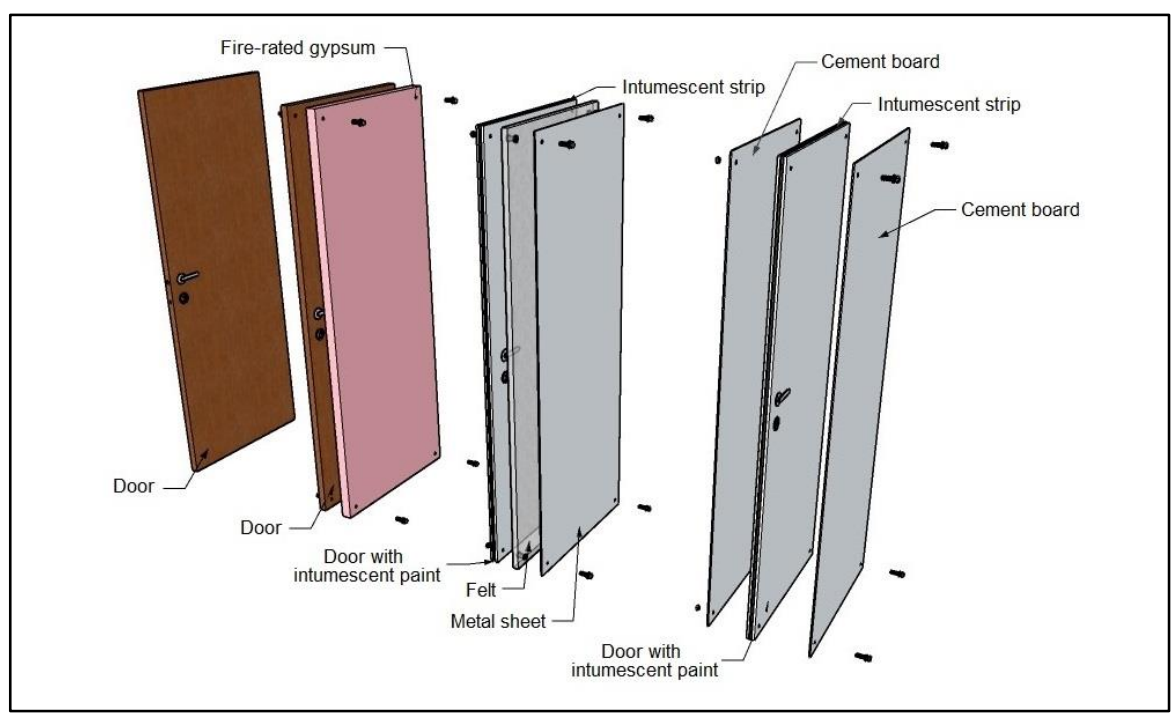

The materials were attached to the doors with bolts, nuts and washers. Table 2 summarizes the properties of specific gravity, thermal conductivity and specific heat capacity of each material in use.

Table 2. Summary of material thermal properties. Source: made based on ABNT (2005); ABNT (1997); Knauf (2018).

\begin{tabular}{|c|c|c|c|c|c|}
\hline Reference & Material & $\begin{array}{l}\text { Specific gravity } \\
\left(\mathrm{kg} / \mathrm{m}^{3}\right)\end{array}$ & $\begin{array}{c}\text { Thermal } \\
\text { conductivity } \\
(\mathrm{W} / \mathrm{m} . \mathrm{K})\end{array}$ & $\begin{array}{c}\text { Specific heat } \\
\text { capacity } \\
\text { (J/kg.K) }\end{array}$ & Reaction to fire \\
\hline $\begin{array}{l}\text { NBR 15220-2 } \\
\text { (ABNT, 2005) }\end{array}$ & \multirow{2}{*}{ Pinus wood } & $300-750$ & $0.12-0.23$ & 1340 & - \\
\hline $\begin{array}{c}\text { NBR } 7190 \\
\text { (ABNT, 1997) }\end{array}$ & & $535-645$ & - & - & - \\
\hline KNAUF (2018) & $\begin{array}{c}\text { Fire-rated } \\
\text { gypsum board }\end{array}$ & $640-960$ & 0.21 & 1000 & $\begin{array}{c}\text { Class II-A } \\
\text { (IT 10/2011 CB) }\end{array}$ \\
\hline- & $\begin{array}{c}\text { Polyethylene } \\
\text { terephthalate } \\
\text { felt }\end{array}$ & 7 & $\begin{array}{c}\leq 0.068 \\
\left(\text { at } 24{ }^{\circ} \mathrm{C}\right)\end{array}$ & - & Class II-A \\
\hline- & Cement board & 1700 & 0.35 & - & Noncombustible \\
\hline $\begin{array}{l}\text { NBR 15220-2 } \\
\text { (ABNT, 2005) }\end{array}$ & Metal sheet & 7800 & 55 & 460 & - \\
\hline
\end{tabular}

\section{Tests}

\section{Ignitability Test}

The test was performed in accordance with EN ISO 11925-2 (EN ISO, 2010) and sought to evaluate the ignitability of the polyethylene terephthalate felt as it was exposed to the flame. According to the standard, all ten test specimens must have standard dimensions, namely, length of $250 \mathrm{~mm}$ and width of $90 \mathrm{~mm}$, whereas four undergo the critical flame position check, which concerns either edge or surface exposure, and six undergo the ignitability test itself.

\section{Fire resistance test for door and shutter assemblies}

The fire resistance test for door and shutter assemblies was performed as per NBR 6479 (ABNT, 1992), in a vertical furnace (Figure 2), following the curve of ISO 834-1 (ISO, 1999). The room temperature at the beginning of the test was measured, and it must remain between 10 and $40^{\circ} \mathrm{C}$ throughout the test. Aside from the apparatus required by the standard, complements were used to help collect data during the test, like laser measure, thermographic camera, and digital chronometer with display to keep track of the test timing. 
Figure 2. Sample assembled and vertical test furnace. Source: elaborated by the authors.
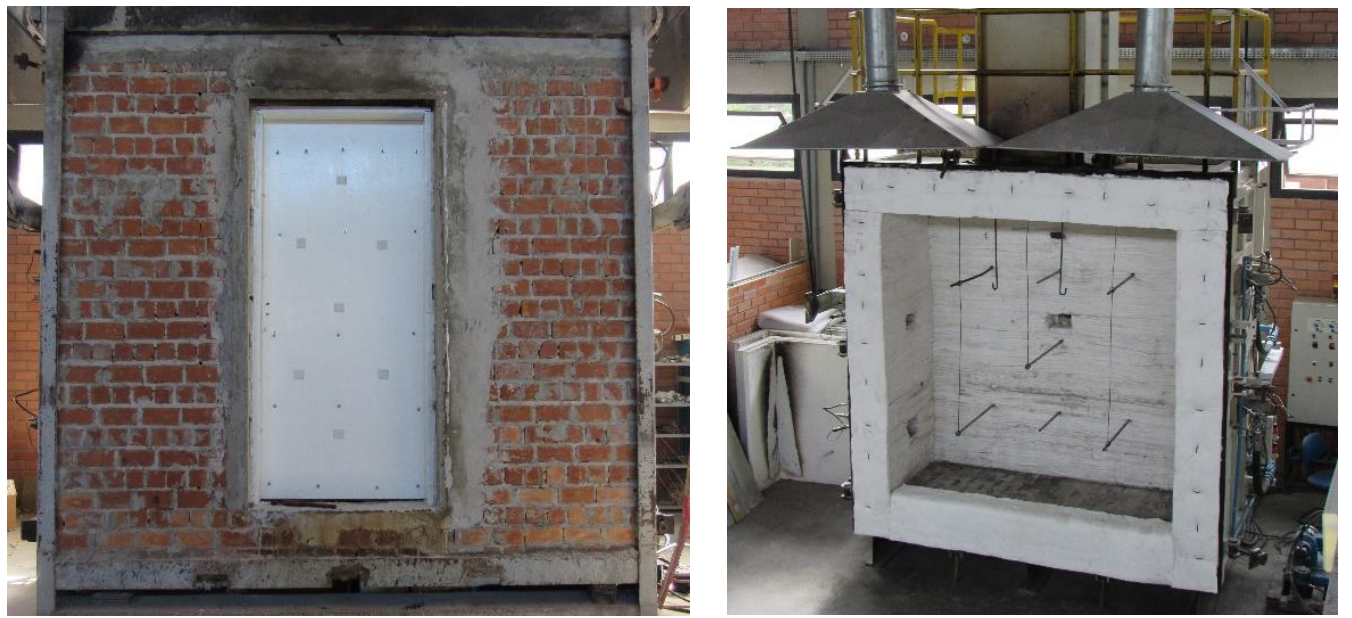

NBR 6479 (ABNT, 1992) requires a minimum of five thermocouples, one placed in front of the geometric center of the specimen and the others in front of the specimen vertices. The thermocouples must not be placed on the door hardware, nor within $30 \mathrm{~cm}$ and $15 \mathrm{~cm}$, respectively, of the horizontal and vertical door edges. For each door test, seven external thermocouples (not exposed to fire) and five internal thermocouples were installed, which were respectively numbered as per Figures 3 (a) and 3 (b).
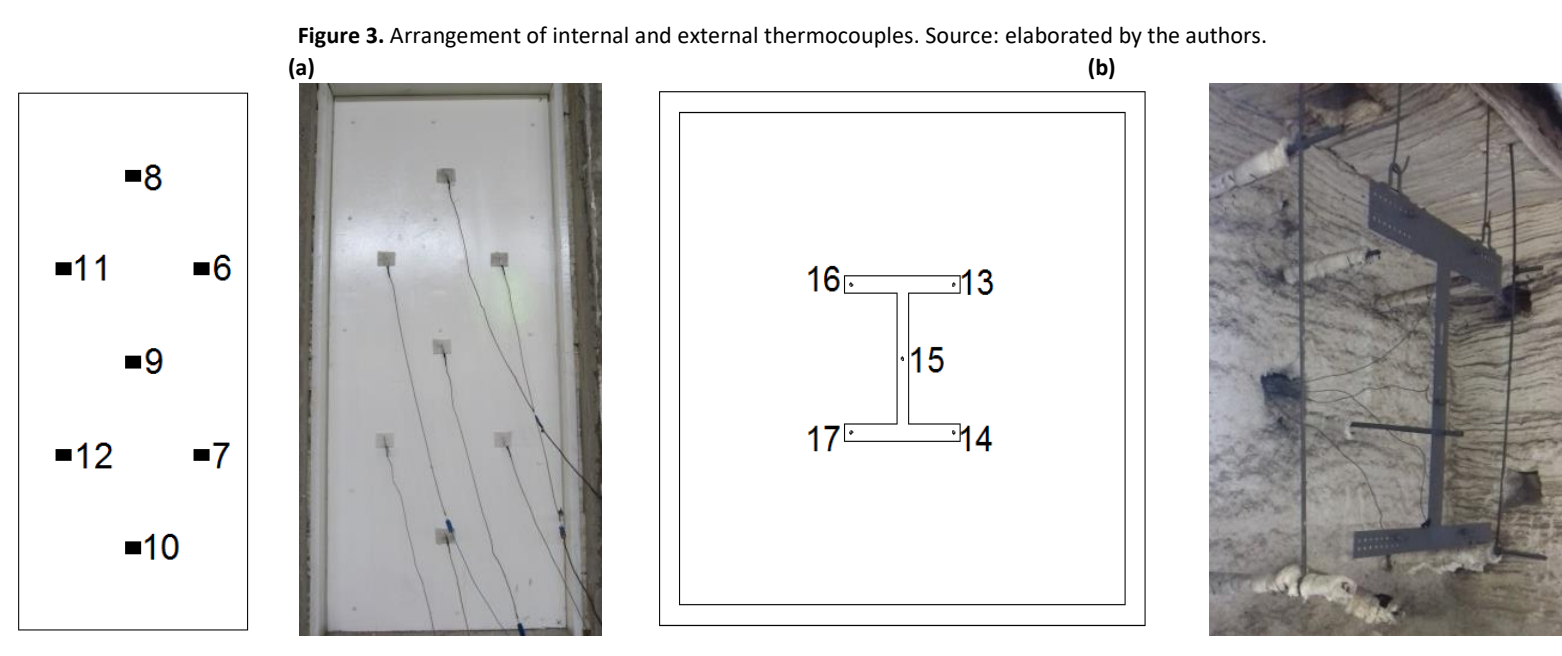

Results and discussion

\section{Ignitability}

Following prescriptions of EN ISO 11925-2 (EN ISO, 2010), the edge exposure application point turned out to be the most critical condition, so the ignitability test was performed on the 6 samples under this configuration.

During the test, 5 out of the 6 samples did not ignite. When brought into contact with the flame, the material was consumed at a specific point without reaching the marking of $150 \mathrm{~mm}$, with no evidence of ignition or flammable particles. Sample 6 was the exception as it ignited and produced flammable particles, possible relating to the variability of the felt fibers.

\section{Fire resistance of door and shutter assemblies}

The fire resistance test was performed on the 4 doors abiding by the instructions of NBR 6479 (ABNT, 1992). The mechanical strength was assessed by observing the total or partial destruction of the samples, along with deformations that could compromise support and closing mechanisms. 


\section{Door D1}

In the first part of the test, the masonry wall that contained door D1 was attached to the furnace (Figure 4a). The room temperature at the beginning of the test was $16.4^{\circ} \mathrm{C}$, complying with the range set by NBR 6479 (ABNT, 1992).

At 20 seconds of testing (Figure 4b), smoke appeared and developed intensively in the seconds that followed (Figure 4c). At 1 minute and 41 seconds, the edges of the door leaf turned black and the burning wood crackled (Figure 4d). At 2 minutes, the crackles intensified (Figure 4e) and at 3 minutes the bottom part flared for less than 10 seconds (Figure 4f). At 3 minutes and 25 seconds of testing, the integrity test was performed without igniting the cotton wad (Figure $4 \mathrm{~g}$ ). At 4 minutes, the test was finished owing to the ignition of the door (Figure 4h). At 4 minutes and 8 seconds (Figure $4 \mathrm{i})$, sparks were seen coming out of the door, which presented vertical cracks.

Figure 4. Test sequence for door D1. Source: elaborated by the authors.

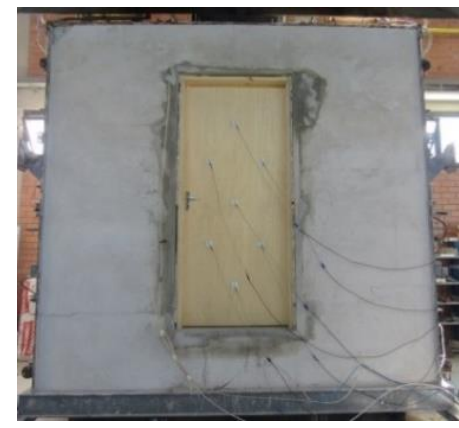

(a)

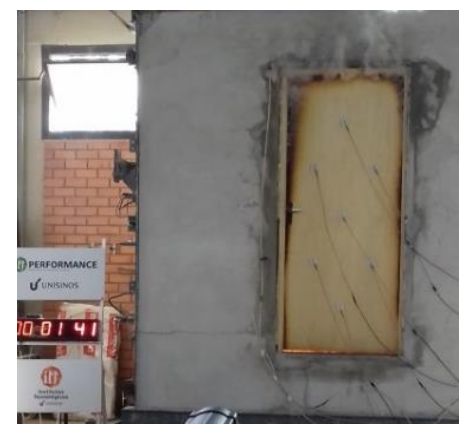

(d)

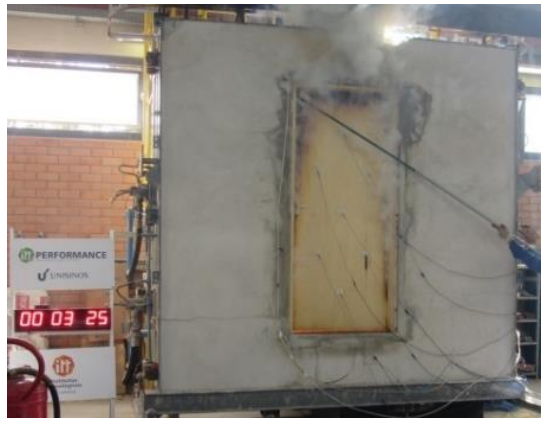

(g)

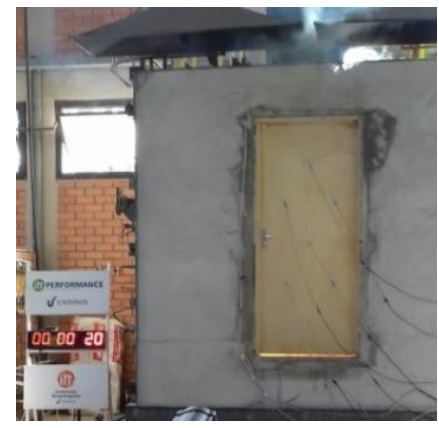

(b)

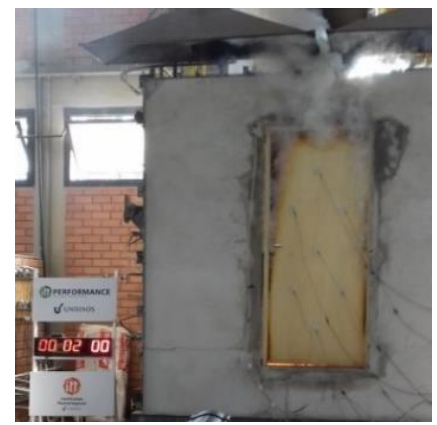

(e)

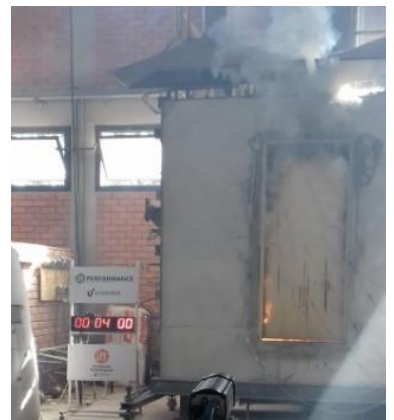

(h)

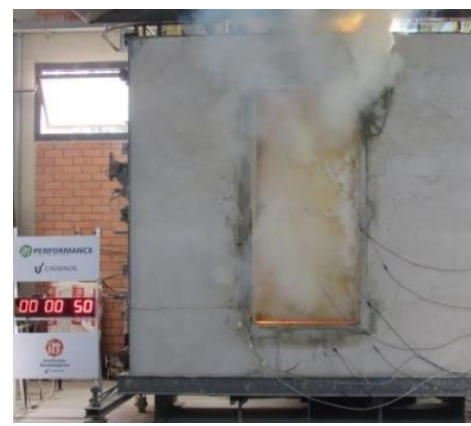

(c)

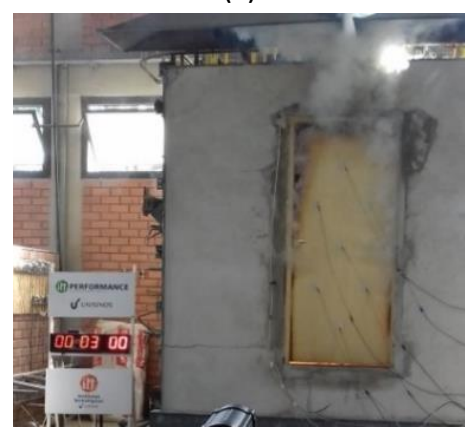

(f)

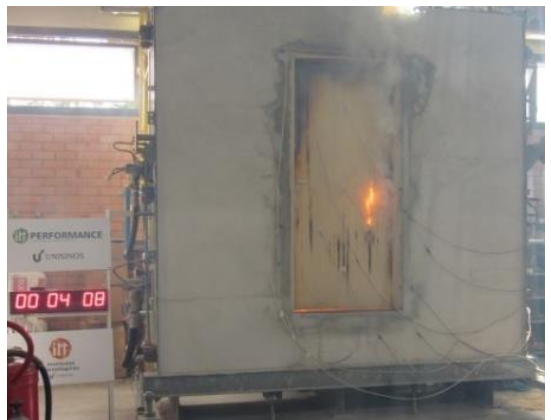

(i)

During the test, as per recommendation of NBR 6479 (ABNT, 1992), the fire resistance criteria of thermal insulation, integrity and mechanical strength were assessed.

In order to evaluate the requirements for thermal insulation, which concern the increase of temperature on the unexposed face, the average temperature on the external thermocouples was taken. Figure 5 demonstrates that the temperature reached higher values on the top part of the sample, more precisely on the top and side corners. 
Figure 5. Thermographic camera recordings for door D1. Source: elaborated by the authors.

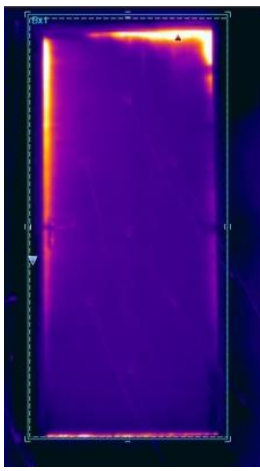

0 min

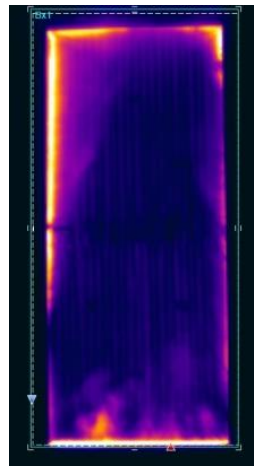

$1 \mathrm{~min}$

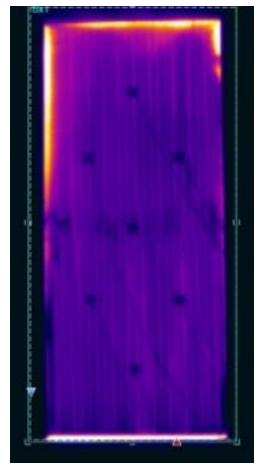

$2 \min$

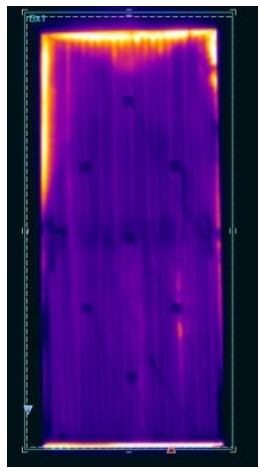

$3 \mathrm{~min}$

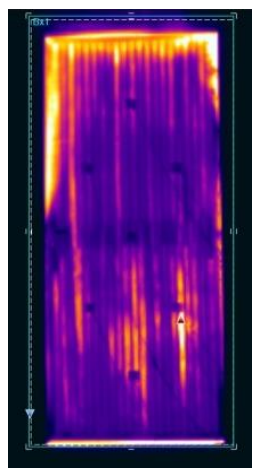

$4 \mathrm{~min}$ $333.2^{\circ} \mathrm{C}$

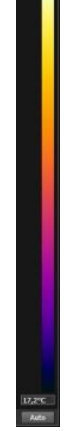

$17.2^{\circ} \mathrm{C}$

Integrity against flames and hot gases was assessed by the ignition of a cotton wad that was placed on the unexposed face at regular intervals. For door D1, the integrity test was performed at 3 minutes and 25 seconds of testing, without igniting the cotton wad. At 4 minutes, though, the door caught on fire, indicating that it failed the air tightness requirement.

The displacements were measured with the laser measure, and the highest displacement of $47 \mathrm{~mm}$ assessed in the top side of the door.

\section{Door D2}

The fire resistance test of door D2 followed the same installation procedures as door D1, but with a fire-rated gypsum board added the unexposed face.

Figure 6 shows that the temperature acted more intensively on the top part of the sample. The absence of edge guards to protect the frame helped the flames reach the top edge of the door faster, revealing a weak spot between the door leaf and the frame. The temperature distribution on the external face of the door lead was different from that of the reference sample D1 and the fire-resistance rating was doubled.

Figure 6. Thermographic camera recordings for door D2. Source: elaborated by the authors.

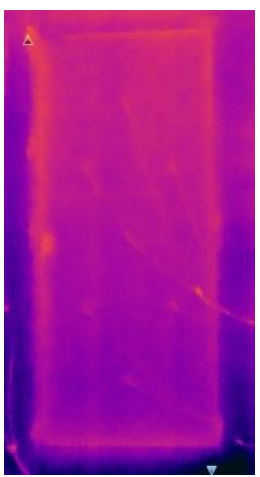

0 min

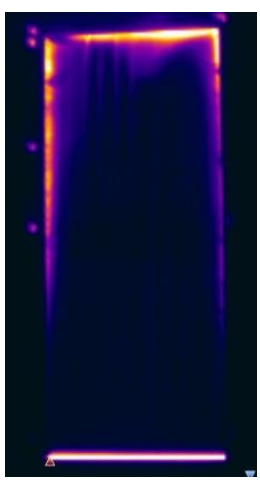

$2 \mathrm{~min}$

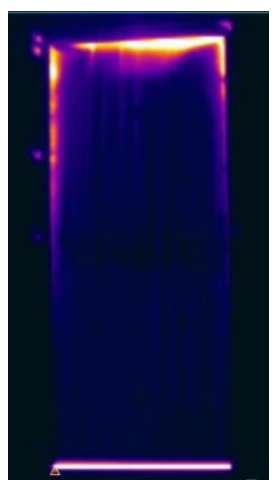

$4 \mathrm{~min}$

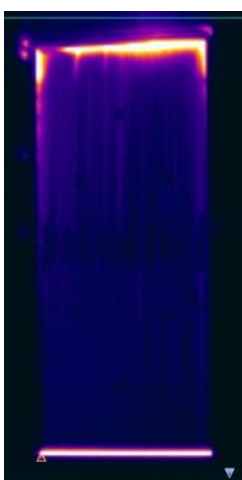

$6 \mathrm{~min}$

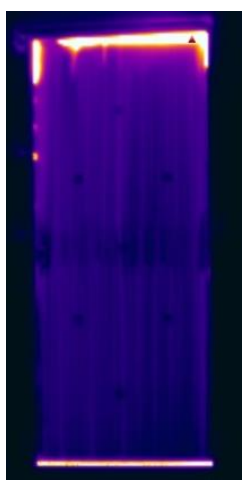

$8 \mathrm{~min}$

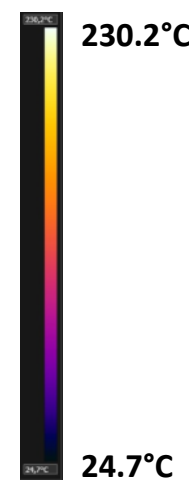

$24.7^{\circ} \mathrm{C}$

For door D2, stronger flaring was detected at 5 and 7 minutes of the integrity test. At 8 minutes, the flaring exceeded 10 seconds, leading to test failure. The highest displacement took place on the top part of the sample, of $17 \mathrm{~mm}$, which was significantly lower than that of the reference sample.

\section{Door D3}

The test of door D3 yielded similarities with respect to the previous samples, with higher temperatures acting on the top part of the door, spreading to the other parts, as depicted in Figure 7. It should be noted that this sample comprised the interaction between 4 materials of different thermal properties, the intumescent paint, metal sheet, polyethylene terephthalate felt and wood. 
Figure 7. Thermographic camera recordings for door D3. Source: elaborated by the authors.

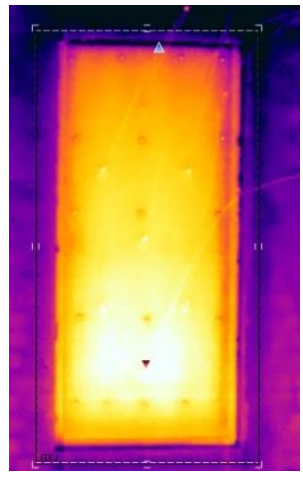

$0 \min$

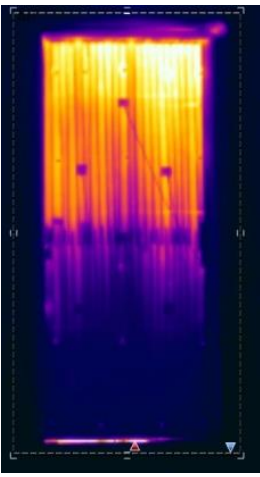

$5 \min$

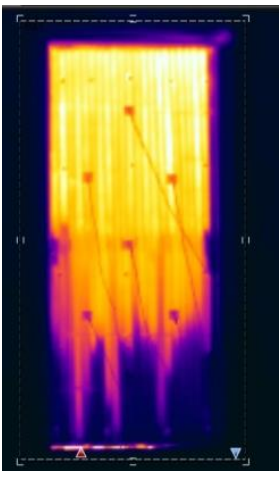

$10 \mathrm{~min}$

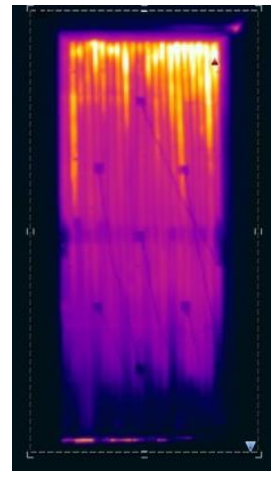

$15 \min$ $199.6^{\circ} \mathrm{C}$

$17.8^{\circ} \mathrm{C}$

The integrity against flames and hot gases was assessed and smoke appeared at 1 minute of testing, despite the presence of the intumescent strip. The integrity tests were performed at 15 and 16 minutes without igniting of the cotton wad. At 17 minutes, though, a side slit flared and led to the end of the test. The highest displacement was of 13 $\mathrm{mm}$, at 18 minutes of testing.

\section{Door D4}

In the test of door D4, it was noteworthy that the temperature intensified by the top part of the sample and then spread to the other parts, just like had happened with the other samples. Figure 8 depicts the temperature evolution along the test.

Figure 8. Thermographic camera recordings for door D4. Source: elaborated by the authors.

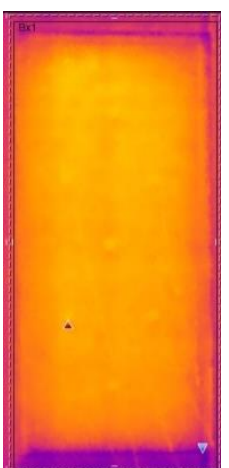

0 min

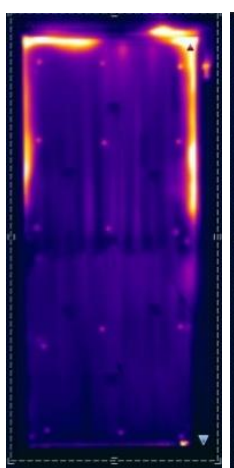

$10 \mathrm{~min}$

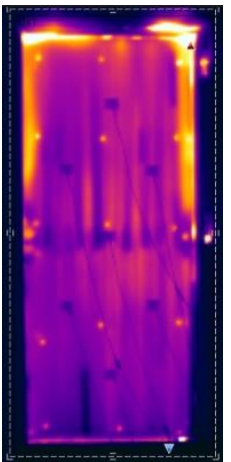

$15 \mathrm{~min}$

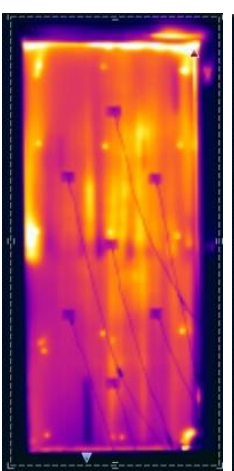

$20 \mathrm{~min}$

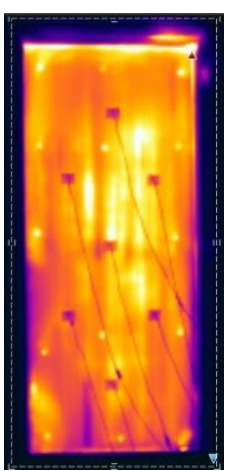

$25 \mathrm{~min}$

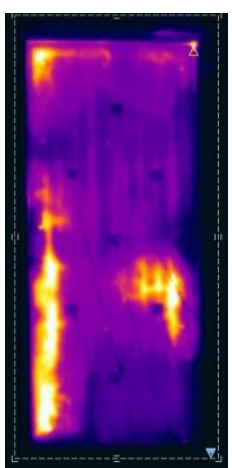

$30 \mathrm{~min}$

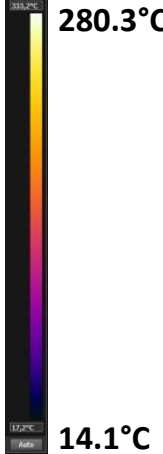

$14.1^{\circ} \mathrm{C}$

A crack appeared on the lower left part of the cement board during the test, at 30 minutes. This sample counted with edge guards to protect the wooden frame. Besides, every material was coated with intumescent paint.

Regardless of the intumescent strip, door D4 presented smoke after 3 minutes of testing. The integrity test was performed at 12, 20, 25, 26, 27, 29 and 30 minutes without igniting the cotton wad. At 33 minutes, the flares surpassed 10 seconds and led to the end of the test. The highest displacement was of $10 \mathrm{~mm}$ on the lower point of analysis, at 25 minutes.

\section{Analysis and correlation of results}

NBR 6479 (ABNT, 1992) determines that a positive result for thermal insulation requires the mean of external thermocouples (not exposed to fire) to be lower than $140^{\circ} \mathrm{C}$ plus room temperature at the beginning of the test. Additionally, the temperature of any external thermocouple cannot be higher than $180^{\circ} \mathrm{C}$ plus room temperature at the beginning of the test. During the four tests, all temperatures met this requirement satisfactorily, as Table 3 shows. 
Table 3. Summary of material thermal properties. Source: elaborated by the authors.

\begin{tabular}{cccc} 
Door & $\begin{array}{c}\text { Time } \\
(\mathrm{min})\end{array}$ & $\begin{array}{c}\text { Mean of external thermocouples at } \\
\text { the end of the test }\left({ }^{\circ} \mathrm{C}\right)\end{array}$ & $\begin{array}{c}\text { Highest temperature point for external } \\
\text { thermocouples at the end of the test }\left({ }^{\circ} \mathrm{C}\right)\end{array}$ \\
\hline D1 & 4 & 92.9 & 115.9 (thermocouple 10) \\
\hline D2 & 8 & 37.4 & 49.8 (thermocouple 8) \\
\hline D3 & 18 & 70.1 & 122.6 (thermocouple 6) \\
\hline D4 & 33 & 69.3 & 136.3 (thermocouple 7) \\
\hline
\end{tabular}

The average temperature of the external thermocouples of doors D2, D3 and D4 was lower than that of door D1. Figure 9 plots the average values that were measured over the testing time of each door. It can be noted that the temperature of door D1 grew faster than the others', while D4 maintained stable temperatures up to around 13 minutes of testing.

Figure 9. Comparison between average temperatures of external thermocouples. Source: elaborated by the authors.

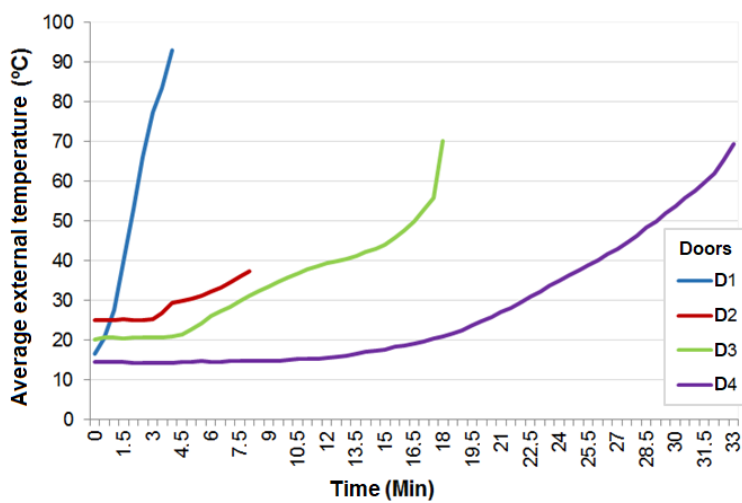

Concerning the temperature of the internal thermocouples, for all samples, central thermocouple 15 recorded the lowest temperature values. During a fire, oxygen is the oxidizing agent that fuels the chemical reaction, therefore this event took place because thermocouple 15 is located on the middle of the sample and away from the gaps, where less oxygen is available. Thermographic images showed that the highest values for every sample took place on the sides and the top part of the sample. In case of indoor fires, hot gases and smoke dissipate by flowing upwards and spreading across the top layer and next to the source of oxygen, the side gaps.

As for the integrity criterion, it was the one to determine the end of all fire resistance tests, specifically at 4 minutes for D1, at 8 minutes for D2, at 17 minutes for D3 and at 33 for D4. In other words, stability and thermal insulation were not the most critical criteria, contrary to what usually happens with most wall systems. It can be noted that gaps are the points that should receive utmost attention to improve the final result.

Finally, door D1 was tested with no insulation so as to estimate its resistance as a parameter for the other doors. Since door D1 resisted for 4 minutes, the additional fire-resistance rating of the other doors, owing to the use of fire-rated materials, was 4 minutes for door D2, 13 minutes for D3, and, 29 minutes for D4, as depicted in Figure 10.

Figure 10. Increase in fire-resistance rating. Source: elaborated by the authors.

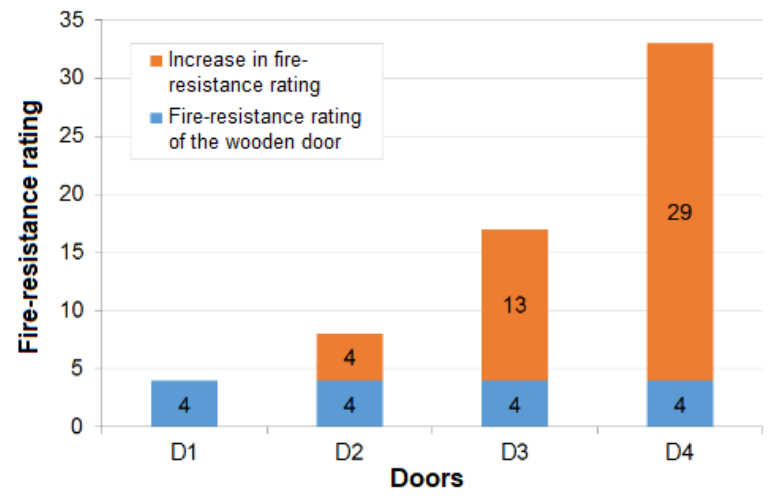


Therefore, as per NBR 6479 (ABNT, 1992), the only sample that fits the category of fire door with minimum fireresistance rating of 30 minutes is door $\mathrm{D} 4$.

The behavior of the samples is deeply related to the materials used and their thermal properties. According to Vargas \& Silva (2005), thermal protection materials must present low bulk specific gravity, high specific heat capacity, low thermal conductivity, proper impact strength, integrity under fire conditions and consistent cost.

Despite having higher specific gravity and thermal conductivity than the fire-rated gypsum boards and the polyethylene terephthalate felt, the cement boards possess the property of non-combustibility, which, added to intumescent paint and wooden frame protection, improved performance regarding fire resistance. It was even the one to provide the most stability to the door leaf as the top and bottom edges deformed towards the fire (Izydorczyk et al., 2017).

Sample D3, regardless of having recieved frame protection and intumescent paint, did not present satisfactory results due to the combustibility of the polyethylene terephthalate felt.

According to Cruz \& Nunes (2005), glue laminated or solid timber structures have higher fire resistance since they present broader transverse sections. This fact would explain the lower fire-resistance rating of door D1, which was semisolid.

Regarding the use of the intumescent strips, they had been installed with the intent of preventing the passage of smoke through the gaps of doors D3 and D4 but did not provide satisfactory insulation. Nevertheless, they showed that most of the smoke dissipated by the top part of the door frame that touched the masonry wall, where no intumescent strips were present.

\section{Conclusions}

This study aimed to evaluate the increase in fire resistance of semi-solid normal wooden doors using materials such as polyethylene terephthalate felt, fire-rated gypsum boards, cement boards and intumescent paint and strips. The results showed that sharp door corners are the spots where wood begins to burn faster than the flat areas.

In this context, it was noted that the integrity criterion was responsible for the end of every test, meaning that the study of gaps is of utmost relevance for the increase in fire resistance of fire doors.

References

ABNT NBR 15220-2. (2005). Desempenho térmico de edificações - Parte 2: Métodos de cálculo da transmitância térmica, da capacidade térmica, do atraso térmico e do fator solar de elementos e componentes de edificações. Associação Brasileira de Normas Técnicas (ABNT). https://www.abntcatalogo.com.br/norma.aspx?ID=59664

ABNT NBR 15281. (2005). Porta corta-fogo para entrada de unidades autônomas e de compartimentos específicos de edificações. Associação Brasileira de Normas Técnicas (ABNT). https://www.abntcatalogo.com.br/norma.aspx?ID=125

ABNT NBR 15930-2. (2018). Portas de madeira para edificações - Parte 2: Requisitos. Associação Brasileira de Normas Técnicas (ABNT). https://www.abntcatalogo.com.br/norma.aspx?!D $=400218$

ABNT NBR 6479. (1992). Portas e vedadores: Determinação da resistência ao fogo. Associação Brasileira de Normas Técnicas (ABNT). https://www.abntcatalogo.com.br/norma.aspx?ID=4161

ABNT NBR 7190. (1997). Projeto de estruturas de madeira. Associação Brasileira de Normas Técnicas (ABNT). https://www.abntcatalogo.com.br/norma.aspx?ID=3395

Asimakopoulou, E., Kolaitis, D., \& Founti, M. (2015). Fire safety aspects of PCM - enhanced gypsum plasterboards: An experimental and numerical investigation. Fire Safety Journal, 72, 50-58. doi: https://doi.org/10.1016/j.firesaf.2015.02.004.

Babrauskas, V. (2005). Charring rate of wood as a tool for fire investigations. Fire Safety Journal, 40, 528-554. doi: https://doi.org/10.1016/j.firesaf.2005.05.006

Brentano, T. (2015). A proteção contra incêndios no projeto de edificações, p. 640, Porto Alegre: Author's edition.

Carlo, U., Seito, A., Gill, A., Pannoni, F., Ono, Rosaria, Silva, S., Carlo, U., \& Silva, V. (2008). A segurança contra incêndio no brasil, p. 496, São Paulo: Projeto Editora.

Cruz, H., Nunes, L. (2005). A madeira como material de construção. Núcleo de Estruturas de Madeira, LNEC, p. 27, Lisboa.

EN ISO 11925-2. (2010). Reaction to fire tests: Ignitability of building products subjected to direct impingement of flame: Part 2: Single-flame source test. European Standard and International Organization for Standardization (EN ISO). 
Faccio, H., \& Silva, A. (2016). As características de reação ao fogo dos materiais de acabamento e de revestimento diante da ABNT NBR $15.575: 2013$. Revista Téchne, 232, 1-8. doi: https://doi.org/10.1016/j.firesaf.2015.02.004.

Gil, A., Pacheco, F., Christ, R., Bolina, F., Khayat, K. H., \& Tutikian, B. (2017). Comparative study of concrete panels' fire resistance. ACl Materials Journal, 114 (5), doi: https://doi.org/10.14359/51689715

Gwynne, S., \& Boyce, K. (2016). Engineering data. In: SFPE Handbook of Fire Protecting Engineering, fifth ed. Springer, pp. $2429-2551$.

ISO 834-1. (1999). Fire-resistance tests - Elements of building construction - Part 1: General requirements. International Organization for Standardization (ISO).

Izydorczyka D., Sędłaka B., Papisa B., \& Turkowskia P. (2017). Doors with specific fire resistance class. Fire Research Department of Building Research Institute. Procedia Engineering, 172, 417-425. doi: https://doi.org/10.1016/j.proeng.2017.02.010

KNAUF. (2018). FIB01 de Knauf Fireboard Systems. Knauf Fireboard Systems Fire Resistance with Premium Drywalling.

Ono, R. (2002). Reabilitação sustentável de edifícios na região central da cidade de São Paulo com ênfase na segurança contra incêndio. In NUTAU: sustentabilidade, arquitetura, desenho urbano (pp. 200-210). São Paulo: Universidade de São Paulo.

Pacheco, F., Christ, R., Quinino, U., \& Tutikian, B. F. (2018). Effects of fiber hybridization in advanced cementitious composites durability in humid and aggressive environments. Revista Materia, 23. doi: https://doi.org/10.1590/s1517-707620180003.0505.

Pinto, E., Calil, C. (2002). Ensaios para avaliação do comportamento de materiais expostos ao fogo: Resistência e Reação. Revista Madeira Arquitetura e Engenharia, 9, 1-10. doi: https://doi.org/10.1016/j.firesaf.2015.02.004.

Purser, D. (2000). Toxic product yields and hazard assessment for fully enclosed design fires. Polym. Int. 49, 1232-1255.

Silva, C. (2010). Avaliação da resistência ao fogo de produtos de construção. Aveiro: Universidade de Aveiro.

Troitzsch, J. (1983). Methods for the fire protection of plastics and coatings by flame retardant and intumescent systems. Progress in Organic Coatings, 11, 41-69. doi: https://doi.org/10.1016/0033-0655(83)80003-X

Vargas, M., \& Silva, V. (2005). Resistência ao Fogo das Estruturas de Aço, p. 72, Rio de Janeiro: IBS/CBCA. doi: https://doi.org/10.13140/2.1.3361.7926 